\title{
PENGARUH KEMOTERAPI TERHADAP PROFIL HEMATOLOGI PADA PENDERITA LEUKEMIA LIMFOBLASTIK AKUT
}

\author{
${ }^{1}$ Eunike Pinontoan \\ ${ }^{2}$ Max Mantik \\ ${ }^{3}$ Novie Rampengan \\ Ilmu Kesehatan Anak FK UNSRAT Manado \\ ikhePin@gmail.com
}

\begin{abstract}
Leukemia atau lebih dikenal kanker pada darah atau sumsum tulang merupakan pertumbuhan sel-sel abnormal tidak terkontrol (sel neoplasma) yang berasal dari hasil mutasi sel normal Kejadian leukemia setiap tahun sekitar 3,5 kasus dari 100.000 anak dibawah 15 tahun. Leukemia pada anak terdiri dari dua tipe yaitu : Leukemia Limfoblastik Akut (LLA) $82 \%$ dan Leukemia Mieloblastik Akut (LMA) 18\%. Puncak kejadian LLA pada usia 2-5 ta hun. Perbandingan penderita perempuan dan laki-laki ialah 1,3:1,5. Data rekam medik BLU RSUP Prof.dr.R.D. Kandou sepanjang tahun 2008-2012, jumlah penderita leukemia limfoblastik akut (LLA) ada sekitar 60 anak yang rawat inap di bagian IKA Prof.Dr.R.D.Kandou Manado. Tujuan: Penelitian ini bertujuan untuk menganalisis pengaruh terapi medis (kemoterapi) terhadap profil hematologi pada penderita Leukemia Limfoblastik Akut (LLA) yang rawat inap di bagian IKA-BLU RSUP Prof.dr.R.D.Kandou.

Metode Jenis penelitian merupakan penelitian analitik dengan menggunakan desain kohort retrospektif. Hasil: Hasil penelitian menunjukkan bahwa profil hematologi penderita LLA yang dirawat di Bagian IKA RS Prof. Dr. R.D Kandou Manado mengalami perubahan setiap minggu.

Kata kunci: Leukemia limfoblastik akut, profil hematologi.
\end{abstract}

\begin{abstract}
Leukemia is commonly known as blood or the bone marrow cancer. The definition of leukemia is an abnormal growth of cells (neoplasm cells) that derived from the mutation of normal cells. The incidence of the leukemia is about 3.5 cases in 100.000 children under 15 years per year. Leukemia in children is divided into two types which are: Acute Lymphoblastic Leukemia (ALL) $82 \%$ and Acute Myeloblastic Leukemia (AML) 18\%. The age two to five years is the right usually age of the incidence of LLA. The ratio between girls and boys is $1.3: 1.5$. The medical record in BLU RSUP Prof. Dr. R.D. Kandou showed that between 2008 and 2012 the total inpatient children with LLA in the Pediatric Department of RSUP Prof. Dr. R.D. Kandou is 60 children. Goal: The goal of this research was to analyze the effect of medical therapy (chemotherapy) on the hematology profile in the LLA patients who were inpatient in the Pediatric Department of RSUP Prof. Dr. R.D. Kandou. Methods: This was a analytic research with the design of retrospective cohort study. Results: This research shows that the hematology profile of LLA patients who were inpatient in the Pediatric Department of RSUP Prof. Dr. R.D. Kandou was weekly changed.
\end{abstract}

Key words: Acute Lymphoblastic Leukemia, hematology profile 


\section{PENDAHULUAN}

Berdasarkan Undang-undang Republik Indonesia nomor 36 tahun 2009 tentang Kesehatan Bab I, kesehatan adalah keadaan sehat baik secara fisik, mental, spiritual maupun sosial yang memungkinkan setiap orang untuk hidup produktif secara sosial dan ekonomis. Sejalan dengan itu peranan orang tua dalam mengenali salah satu kelainan dalam tumbuh kembang anak sangat dibutuhkan termasuk dalam mendeteksi adanya penyakit pada anak. Salah satu penyakit yang mengancam kehidupan seseorang ialah kanker. Leukemia atau lebih dikenal kanker pada darah atau sumsum tulang merupakan pertumbuhan sel-sel abnormal tidak terkontrol (sel neoplasma) yang berasal dari hasil mutasi sel normal. Adanya pertumbuhan sel neoplasma ini ditandai oleh perbanyakan secara tidak normal atau transformasi maligna dari sel-sel pembentuk darah di sumsum tulang dan jaringan limfoid yang umumnya terjadi pada leukosit (sel darah putih) pertumbuhan sel-sel abnormal ini mengganggu fungi normal dari organ-organ vital dan dapat menyebar ke seluruh tubuh. ${ }^{1,2}$

Data dari World Health Organization (WHO) menunjukkan bahwa angka kematian di Amerika Serikat disebabkan oleh leukemia meningkat dua kali lipat sejak tahun $1971 .^{3}$ Pada tahun 2007 American Cancer Society melaporkan, penyakit kanker menempati urutan kedua dunia penyebab kematian setelah penyakit jantung. ${ }^{4}$ International Cancer Parent Organization (ICPO) menunjukkan bahwa dari setiap satu juta anak terdapat 120 anak yang mengidap kanker dan $60 \%$ diantaranya disebabkan oleh leukemia. ${ }^{5}$ Kejadian leukemia setiap tahun sekitar 3,5 kasus dari 100.000 anak dibawah 15 tahun. Leukemia akut pada anak mencapai $97 \%$ dari semua leukemia pada anak yang terdiri dari 2 tipe yaitu : Leukemia Limfoblastik Akut (LLA) 82\% dan Leukemia Mieloblastik Akut (LMA) 18\%. Leukemia limfobastik akut adalah kanker yang sering terjadi pada anak. Kasus baru LLA per tahun terjadi sebanyak kurang lebih 3000 di Amerika, 5000 di Eropa ${ }^{6}$ dan diperkirakan 2000-3000 kasus di Indonesia. ${ }^{7}$ Puncak kejadian LLA pada usia 2-5 tahun. Perbandingan penderita perempuan dan laki-laki ialah 1,3:1,5. ${ }^{8}$ Kejadian leukemia di dunia mencapai $30-40 \%$ dari seluruh keganansan pada anak. Hal ini membuktikan bahwa penyakit leukemia merupakan masalah kesehatan yang serius terutama dampaknya pada anak-anak. Setiap tahun ada sekitar 1000 kasus baru (20-25/juta populasi) untuk LMA dan LLA di Inggris, LLA merupakan keganasan yang paling sering terjadi pada masa anak-anak (usia puncak 4 tahun) tetapi juga terjadi pada orang dewasa. LMA terjadi pada semua usia, tetapi pada masa anak-anak lebih jarang terjadi dibandingkan LLA dan paling sering terjadi pada orang berusia lanjut. ${ }^{9}$

Insiden rata-rata 4-4,5 kasus/tahun/100.000 anak dibawah 15 tahun. Di negara berkembang $83 \%$ LLA, 17\% LMA, lebih tinggi pada anak kulit putih dibandingkan kulit hitam. Di Asia kejadian leukemia pada anak lebih tinggi dari pada anak kulit putih. Di Jepang mencapai 4/100.000 anak dan diperkirakan tiap tahun terjadi 1000 kasus baru. $^{9}$

Di Indonesia berdasarkan survey Kesehatan Rumah Tangga (SKRT) tahun 2001, penyakit kanker merupakan penyebab kematian nomor lima di Indonesia. $^{10}$ Berdasarkan Riset Kesehatan Dasar (Riskesdas) tahun 2007, prevalensi kanker di Indonesia adalah 4,3 per 1000 penduduk. ${ }^{11}$ Umumnya, penderita kanker anak datang setelah masuk stadium lanjut yang sulit untuk disembuhkan. Pada tahun 2006 jumlah penderita leukemia rawat inap di Rumah Sakit di Indonesia sebanyak 2.513 orang.

Berdasarkan data rekam medik BLU RSUP Prof.dr.R.D. Kandou sepanjang tahun 2008-2012 jumlah penderita anak yang menderita leukemia limfoblastik akut (LLA) ada sekitar 60 anak yang rawat inap di bagian Estella BLU Prof.dr.R.D.Kandou Malalayang. ${ }^{12}$

Berbagai cara telah dilakukan untuk dapat mengobati penyakit ini, salah satunya dengan cara kemoterapi. Kemoterapi merupakan jenis pengobatan yang menggunakan obat-obatan untuk membunuh sel-sel neoplasma. Pengobatan semacam ini telah digunakan sejak tahun 1950-an. Di lain pihak terdapat efek samping yang ditimbulkan oleh obatobat kemoterapi yang tidak hanya membunuh sel-sel leukemia tetapi juga menyerang sel-sel normal. Salah satu cara untuk mengevaluasi keberhasilan kemoterapi dilakukan pemerikaan hematologi rutin. ${ }^{13}$ 
Meningkatnya prevalensi penyakit LLA pada anak di dunia termasuk di Indonesia dan khususnya di Sulawesi Utara mendorong peneliti untuk mengadakan penelitian tentang pengaruh kemoterapi terhadap fase perkembangan penyakit LLA pada anak yang di rawat di bagian Estella BLU Prof.dr.R.D. Kandou Manado periode 2008-2012.

\section{Perumusan Masalah}

Bagaimanakah pengaruh kemoterapi terhadap profil hematologi pada penderita leukemia limfoblastik akut (LLA) yang di rawat di bagian Estella BLU Prof.dr.R.D. Kandou Manado periode 2008-2012 ?

\section{Tujuan penelitian}

Menganalisis pengaruh terapi medis (kemoterapi) terhadap profil hematologi pada penderita Leukemia Limfoblastik Akut (LLA) yang rawat inap di bagian IKA-BLU RSUP Prof.dr.R.D.Kandou

\section{Manfaat Penelitian}

Sebagai bahan informasi dan pertimbangan bagi tenaga kesehatan dalam upaya pengobatan penyakit kanker dan menjadi data dasar bagi penelitian lanjut mengenai terapi yang berpengaruh terhadap perkembangan penyakit Leukemia Limfoblastik Akut.

\section{METODE PENELITIAN}

Penelitian berlokasi di bagian Ilmu kesehatan anak RSUP Prof. dr. R.D. Kandou pada bulan Desember 2012-Januari 2013. Jenis penelitian menggunakan desain kohort retrospektif. Data yang diambil ialah yang sesuai kriteria inklusi : data lengkap dan yang dieksklusi ialah pasien yang meninggal pada fase induksi.

Definisi operasional:

1. LLA yang dimaksud adalah Leukemia penyakit keganasan sel darah yang berasal dari sumsum tulang, ditandai oleh proliferasi selsel darah putih dimana subyek penelitian sebelumnya telah dinyatakan oleh dokter ahli menderita penyakit LLA berdasarkan gejala klinik, pemeriksaan penunjang.

2. Profil hematologi : Yang dimaksudkan ialah kadar hematologi masing-masing penderita setelah kemoterapi pada fase induksi.

a).Hemoglobin normal yaitu 1217,5g/dl. Pada leukemia kadar hemoglobin akan menurun. ${ }^{14}$ 6 bulan -6 tahun : $10,5-14,0$ $7-13$ tahun : $11,0-16,0$

b). Leukosit normal yaitu 5000$10000 / \mathrm{mm}^{3}$. Pada leukemia, leukosit bisa normal, tinggi atau rendah. ${ }^{14}$

6 bulan -6 tahun : 6000-15000

7 tahun- 13 tahun : $4500-13500$

c). Trombosit normal yaitu $150000-$ $400000 / \mathrm{mm}^{3}$. Pada leukemia terjadi trombositopenia. ${ }^{14}$ 6 bulan -6 tahun : $150000-400000$ 7 tahun - 13 tahun : 170000 380000

3. Jenis kelamin :Yang dimaksudkan ialah semua anak yang didiagnosis leukemia limfoblastik akut.

4. Umur: penderita dibagi berdasarkan data yang tercantum pada catatan medis dengan pembagian : 6 bulan -6 tahun, 7 tahun - 13 tahun

5. Pengaruh kemoterapi : Yang dimaksud adalah kadar hematologi setelah pemberian kemoterapi pada fase induksi. 
HASIL PENELITIAN

\begin{tabular}{lrc}
\hline Karakteristik & $\begin{array}{c}\text { Jumlah } \\
\text { penderita }\end{array}$ & Persentase \\
\hline Umur & & $50 \%$ \\
6 bulan -6 & 22 & $50 \%$ \\
tahun & $\begin{array}{r}\text { orang } \\
7 \text { tahun }-13\end{array}$ & 22 \\
tahun & orang & \\
Jenis & & \\
Kelamin & & $61 \%$ \\
Laki-laki & 27 & $39 \%$ \\
Perempuan & orang & $100 \%$ \\
Total & 17 & \\
& orang & \\
& 44 & \\
\hline
\end{tabular}

Tabel 1. Karakteristik jumlah penderita LLA berdasarkan usia dan jenis kelamin

menunjukkan karakteristik penderita berdasarkan umur dan jenis kelamin, data diperoleh dari 44 penderita yang memenuhi kriteria inklusi. Ditinjau dari usia, jumlah penderita yang berusia enam bulan sampai enam tahun sama jumlahnya dengan penderita yang berusia tujuh tahun sampai 13 tahun sebanyak 22 orang (50\%). Jumlah penderita perempuan sebanyak 17 orang (39\%) dan penderita laki-laki berjumlah 27 orang (61\%), dari data yang diperoleh menunjukkan bahwa jumlah penderita laki-laki lebih banyak dibandingkan jumlah penderita perempuan.

Tabel 2. Kadar hematologi normal menurut umur pada fase induksi

\begin{tabular}{lcccccc}
\hline Fase induksi & \multicolumn{3}{c}{ 6 bulan - 6 tahun } & \multicolumn{3}{c}{ 7 Tahun - 13 Tahun } \\
\cline { 2 - 7 } & Hb & Leukosit & Trombosit & Hb & Leukosit & Trombosit \\
Minggu I & 6 & 3 & 5 & 5 & 14 & 8 \\
Minggu II & 9 & 2 & 7 & 5 & 13 & 7 \\
Minggu III & 7 & 6 & 9 & 12 & 10 & 6 \\
Minggu IV & 9 & 7 & 7 & 6 & 6 & 10 \\
\hline
\end{tabular}

Pada tabel 2 menunjukkan pengaruh kemoterapi melalui nilai hematologi berdasarkan pembagian usia dari fase induksi. Pada minggu I terdapat enam penderita yang memiliki kadar hemoglobin normal untuk umur 6 bulan sampai enam tahun, berbeda dengan minggu II, IV mencapai sembilan orang dan pada minggu III terdapat tujuh orang, di mana masing-masing penderita berbeda setiap minggu. Untuk leukosit terdapat tiga penderita yang memiliki kadar leukosit normal pada minggu I, minggu II dua orang, mingu III enam orang dan minggu IV terdapat tujuh orang. Untuk trombosit pada minggu I ada lima orang memiliki kadar trombosit normal, minggu II dan IV ada tujuh orang dan terdapat Sembilan orang pada minggu III.

Ditinjau dari usia tujuh tahun sampai 13 tahun, pada minggu I dan II terdapat lima penderita yang memiliki kadar hemoglobin normal, minggu III 12 orang dan minggu IV berjumlah enam penderita dengan masingmasing berbeda setiap minggu2nya. Untuk leukosit pada minggu I terdapat 14 penderita yang memiliki kadar leukosit normal, 13 penderita pada minggu II, 10 penderita minggu III dan 6 penderita minggu IV. Untuk trombosit terdapat delapan penderita yang memiliki nilai trombosit normal, tujuh penderita minggu II, enam penderita minggu III dan pada minggu IV terdapat 10 penderita.

\section{PEMBAHASAN}

Hasil penelitian yang diperoleh menunjukkan bahwa insiden LLA terbanyak terdapat pada usia kurang dari 10 tahun, puncak insiden ialah pada usia dua sampai delapan tahun dan lebih banyak terjadi pada anak laki-laki. Profil hematologi pada penderita leukemia bervariasi mulai ringan sampai berat. Penelitian ini sejalan dengan hasil penelitian Widiaskara dkk yang menemukan umumnya kadar hemoglobin rendah terdapat pada penderita awal induksi sedangkan kadar hemoglobin lebih dari $10 \mathrm{gr} / \mathrm{dl}$ terdapat pada penderita yang telah mendapat transfusi 
sebelumnya. Dapat terjadi leukopenia, leukositosis atau leukosit normal dan paling sering terjadi trombositopenia. Nilai leukosit yang diharapkan pada hasil kemoterapi adalah leukopenia hal ini sejalan dengan penelitian Mulatsih dkk yang menyatakan bahwa jumlah leukosit merupakan prognosis terhadap keberhasilan pengobatan. Dari hasil yang diperoleh maka disimpulkan bahwa kadar hematologi penderita LLA pada fase induksi mengalami perubahan setiap minggu.

\section{UCAPAN TERIMA KASIH}

Ucapan terima kasih kepada 1). Dr. Stefanus Gunawan, MSi, $\operatorname{SpA}(\mathrm{K})$, Dr. Rocky Wilar, $\operatorname{SpA}(\mathrm{K})$ atas arahan, bimbingan serta koreksi dalam penyelesaian penelitian ini, 2). Semua perawat Estella RSU Prof. dr. R.D Kandou yang telah membantu dalam pengambilan data rekam medis penderita LLA, 3) Semua pihak baik secara langsung maupun tidak langsung telah membantu menemukan ide dan gagasan yang baik dalam penyelesaian penelitian ini.

\section{DAFTAR PUSTAKA}

1. Undang-Undang Republik Indonesia. Jakarta; 2009. Tentang kesehatan. Di akses dari: dinkessulsel.go.id/ne.1.uu36-09-

kesehatan.pdf. 16 oktober 2012

2. Anky TR, Aisyi M, Sari Y, Edi ST. Karakteristik leukemia limfoblastik akut pada anak di RS Kanker Dharmais 2000-2008. 4 Oktober 2010; diterima tanggal 17 juni 2009, disetujui 8 Oktober 2010. Di akses dari

http://indonesianjournalofcancer.org/ 2010-no4-oct-dec/141-karakteristikleukemia-limfoblastik-akut-padaanak-di-rumah-sakit-kankerdharmais-2000-2008. 18 oktober 2012

3. Stiller C. WHO ENHIS: incindence of childhood leukemis. Desember 2009. Di akses dari: http://www.scribd.com/doc/76706170 /PKM-GT-344.2012

4. American Cancer Society. Atlanta, Georgia: The Association; 2012. Leukemia acute myeloid (myelogenous). Di akses dari: www.cancer.org/leukemia--acutemyeloid--myelogenous--pdf. November 2012

5. International Cancer Parent Organization. The Association; 2011. Di akses dari http://www.uicc.org/membership/inte rnational-confederation-childhoodcancer-parent-organisations-icccpo 16 oktober 2012

6. Margolin J, Steuber CP, Poplack DG. Acute lymphoblstic leukemia. In: Pizz PA, Poplack DG, editors. Principles and practice of pediatric oncology. $\quad 4^{\text {th }}$ ed. Philadelphia: Lippincott Williams \& Wilkins; 2002: pp. 489-544. Diakses dari : http://indonesianjournal.saripediatri/2 012/aug-leukemia-limfoblastik-akut

7. Sutaryo, Sumadiono, Suhai. The pilot protocol of wijaya usuma acute lymphoblastic leukemia childhood 1999. Yogyakarta : Indonesian Multicentre Study, Gadjah Mada University Press; 1999.

8. Hamidah M. Leukemia pada anak dan deteksi dini. 2010. Di akses dari http://www.asiancancer.com/indonesi an/cancer.

9. Permono B, Sutaryo H, Ugrasena I, Windistuti E, Abdulsalam M.

Hematologi - onkologi anak. Jakarta: Badan Penerbit IDAI; 2006. p.23637.

10. Widyastuti W. Departemen Kesehatan RI survey kesehatan rumah tangga: studi kesehatan ibu dan anak. Indonesia. 2002

11. Departemen Kesehatan RI: Laporan Riset Kesehatan Dasar. Indonesia. 2007

12. Data rekam medik BLU RSUP Prof. dr. R.D. Kandou Malalayang. Manado. 2012

13. Greaves MF. Speculation on the cause of childhood acute lymphoblastic leukemia. In: Permono B, Sutaryo, Ugrasena I, Windiastuti E, Abdulsalam M, editors. 
Hematologi onkologi anak. $2^{\text {nd }}$ ed.

Badan Penerbit IDAI; 2006. pp. 236-

37

14. Berhman, Kliegman, Alvin, Wahab S. Anemia. Dalam: Buku Ilmu Kesehatan Anak Nelson. Edisi 1. Jakarta : EGC; 2000. Pp. 1689-81 